\title{
Mechanism of Antibacterial Antibiotic Sensitivity in Pythium ultimum
}

\author{
By CARROLL D. RAWN AND JAMES L. VAN ETTEN \\ Department of Plant Pathology, University of Nebraska, \\ Lincoln, Nebraska 68583, U.S.A.
}

(Received 25 January 1978)

\begin{abstract}
The unusual sensitivity of a Pythium ultimum isolate to three inhibitors of prokaryote protein synthesis [tetracycline (TET), chloramphenicol (CAM), erythromycin (ERY)] was investigated. TET inhibited growth in shake culture by $40 \%$ at $10 \mu \mathrm{g} \mathrm{ml}^{-1}$ and $99 \%$ at $100 \mu \mathrm{g} \mathrm{ml}^{-1}$ within $5 \mathrm{~h}$ (one doubling period). CAM inhibited growth by $40 \%$ at $500 \mu \mathrm{g} \mathrm{ml}^{-1}$ and $70^{\%}$ at $1 \mathrm{mg} \mathrm{ml}^{-1}$. Cycloheximide $(\mathrm{CHI})$, a eukaryote protein synthesis inhibitor, blocked growth completely at $1 \mu \mathrm{g} \mathrm{ml}^{-1}$. These agents reduced incorporation of leucine and phenylalanine into protein by 40 to $50 \%\left(100 \mu \mathrm{g} \mathrm{TET} \mathrm{ml}^{-1}, 500 \mu \mathrm{g} \mathrm{CAM} \mathrm{ml}^{-1}\right)$ or $93 \%$ $\left(1 \mu \mathrm{g} \mathrm{CHI} \mathrm{ml}{ }^{-1}\right)$ within $20 \mathrm{~min}$. This rapid inhibitory effect could not be attributed to impaired mitochondrial energy generation. TET inhibition increased to $90 \%$ by $60 \mathrm{~min}$, but CAM inhibition did not change for $5 \mathrm{~h}$. TET inhibited both the transport and protein synthetic (cytoplasmic) components of amino acid incorporation, but CAM impaired only the transport activity. CHI blocked protein synthesis, but did not inhibit transport detectably. In contrast to these results, growth inhibition by ERY did not increase with dose ( $40 \%$ inhibition at 10 to $500 \mu \mathrm{g} \mathrm{ml}^{-1}$ ), and ERY at $500 \mu \mathrm{g} \mathrm{ml}^{-1}$ inhibited neither amino acid transport nor protein synthesis in 5 h. The results indicate that the sensitivity of $P$. ultimum to these prokaryote inhibitors reflects unusual permeability properties, which account for impaired transport (CAM, TET) and allow access of the drugs to sensitive intracellular sites, the cytoplasmic (TET) and mitochondrial (ERY) protein synthetic systems.
\end{abstract}

\section{INTRODUCTION}

The Pythiaceae are unusual among fungi in that they are sensitive to relatively low concentrations ( 25 to $100 \mu \mathrm{g} \mathrm{ml}^{-1}$ ) of several antibacterial antibiotics such as tetracycline and chloramphenicol (Hendrix, 1974; Tsao, 1970). At such concentrations these drugs characteristically inhibit protein synthesis in vivo in prokaryotes but not in eukaryotes. Marchant \& Smith (1968) reported decreased amounts of some cytochromes in a Pythium ultimum isolate treated with chloramphenicol. Synthesis of cytochromes requires coordinate production of peptides on both the cytoplasmic and mitochondrial ribosomes (Schatz \& Mason, 1974). Carnes \& Leary (1977) recently reported that amino acid incorporation into protein by isolated mitochondria of Phytophthora palmivora was inhibited by chloramphenicol. Mitochondria isolated from a mutant of the fungus did not show this effect, nor was the mutant's growth inhibited by the drug. Therefore, results of both of these investigations suggested that the mitochondrial ribosome is a site of chloramphenicol action.

The mitochondrial protein synthetic system of eukaryotes is now generally regarded as having prokaryotic traits, distinct from those of the cytoplasmic protein synthetic system. Amino acid incorporation into protein by isolated mitochondria from a variety of eukaryotes is inhibited by low concentrations of chloramphenicol (Schatz \& Mason, 1974; Pestka, 
1975; Lamb et al., 1968; Grivell, 1967; De Vries et al., 1971). Thus inhibition of the mitochondrial system does not explain the unusual antibiotic sensitivity of the pythiaceous fungi.

A major problem in the characterization of drug sensitivity in the Pythiaceae has been the customary treatment of the fungi with the antibiotics for many hours or days; lengthy treatments amplify the likelihood of multiple or non-specific effects. With few exceptions, reports of antibiotic sensitivity of these fungi have related only to growth inhibition (Tsao, 1970). Recently we have developed a procedure which allows the detection of short-term effects of antibiotics on these fungi; for example, tetracycline and chloramphenicol were found to inhibit amino acid incorporation by a Pythium ultimum isolate within $30 \mathrm{~min}$ (Rawn \& Van Etten, 1977). The purpose of this investigation was to describe the trait(s) which confers drug sensitivity in a Pythium ultimum isolate.

\section{METHODS}

Growth inhibition assays. Pythium ultimum Trow was grown in shake culture in a defined medium as previously described (Rawn \& Van Etten, 1978). It grew as a uniform suspension of individual hyphae and small pieces of mycelium, with a doubling time of about $5 \mathrm{~h}$. Reproducible sampling of small volumes of actively growing cell material was therefore possible. In assays of antibiotic effects on growth, triplicate $100 \mathrm{ml}$ samples of actively growing culture material were incubated with antibiotics for 5 or $24 \mathrm{~h}$ in $250 \mathrm{ml}$ Erlenmeyer flasks with shaking $\left(100 \mathrm{rev} . \mathrm{min}^{-1}\right.$, rotary shaker, $\left.25^{\circ} \mathrm{C}\right)$. Eefore and after drug treatment $10 \mathrm{ml}$ samples were withdrawn from flasks with a $10 \mathrm{ml}$ wide-tipped pipette, filtered and dried to a constant weight at $100{ }^{\circ} \mathrm{C}$.

Incorporation of radioactive precursors. The procedure for measuring incorporation of $\left[{ }^{3} \mathrm{H}\right]$ leucine or $\left[{ }^{14} \mathrm{Clacetate}\right.$ into trichloroacetic acid (TCA)-insoluble material, as well as the precursor stocks used, have been described previously (Rawn \& Van Etten, 1978). Briefly, $3 \mathrm{ml}$ culture samples were incubated with various antibiotics or respiratory inhibitors and then pulse-labelled with the radioactive precursors. after which TCA-insoluble radioactivity was measured. The same procedure was used for measuring incorporation into Saccharomyces cerevisiae, grown under the same culture conditions as $P$. ultimum. The durations of the various treatments are specified in Results. Scintillation counting efficiencies were $7 \%$ with ${ }^{3} \mathrm{H}$ and $50 \%$ with ${ }^{14} \mathrm{C}$.

Transport of $\left[{ }^{3} \mathrm{H}\right]$ leucine. Five ml culture samples were incubated for 15 or 45 min with $1 \mu \mathrm{g}$ cycloheximide $\mathrm{ml}^{-1}$ plus varicus antibacterial drugs and then pulse-labelled for $15 \mathrm{~min}$ with $\left[{ }^{3} \mathrm{H}\right]$ leucine. The samples were filtered quickly on to Whatman $3 \mathrm{MM}$ paper discs, washed four times with $10 \mathrm{ml}$ cold distilled water, and then immersed in $5 \mathrm{ml} 80 \%(\mathrm{v} / \mathrm{v})$ ethanol $\left(90^{\circ} \mathrm{C}\right)$ to extract free intracellular leucine. After $15 \mathrm{~min}$ extraction, samples were counted in a Triton/toluene solution (Van Etten et al., 1973), with about $35 \%$ efficiency. Separate samples were dried on paper discs, washed with five changes of $5 \%(\mathrm{w} / \mathrm{v})$ TCA and three changes of ethanol/ether $(1: 1, \mathrm{v} / \mathrm{v})$ and then dried. The TCA-insoluble radioactivity on the discs was measured as previously described (Rawn \& Van Etten, 1978). This TCA-insoluble radioactivity was subtracted from the total ethanol-soluble radioactivity to give the reported values of free intracellular leucine.

All data reported are typical of results obtained in three or more experiments with triplicate samples per treatment within experiments.

Antibiotics. Tetracycline, cycloheximide, erythromycin, streptomycin sulphate, penicillin G (sodium salt) and $\mathrm{D}(-)$-threo-chloramphenicol were obtained from Sigma.

\section{RESULTS}

\section{Antibiotic effects on growth}

With a treatment of $5 \mathrm{~h}$ (one doubling period), the lowest growth inhibitory concentrations of the antibacterial drugs tested were $10 \mu \mathrm{g} \mathrm{ml}^{-1}$ for tetracycline (TET) or erythromycin (ERY) and $500 \mu \mathrm{g} \mathrm{m}^{-1}$ for chloramphenicol (CAM) (Table 1). Cycloheximide (CHI) at $1 \mu \mathrm{g} \mathrm{ml}^{-1}$ inhibited growth completely. The TET and ERY minimal inhibitory concentration was only slightly greater than that typical for bacterial growth inhibition. In separate experiments, increases in CAM concentration increased the growth inhibition, to a maximum of about $70 \%$ at $1 \mathrm{mg} \mathrm{ml}^{-1}$. In contrast to the results with TET and CAM, growth inhibition by ERY did not increase significantly with increasing dose. Treatment of the fungus for $24 \mathrm{~h}$ increased the growth inhibition by all three antibacterial drugs (Table 1). 
Table 1. Effect of antibiotics on dry weight increase of Pythium ultimum in shake culture

Cultures $(100 \mathrm{ml})$, growing at a doubling rate of $5 \mathrm{~h}$, were incubated with antibiotics for 5 or $24 \mathrm{~h}$. Dry weights of $10 \mathrm{ml}$ samples were determined before and after treatment. Representative control dry weights were 2 and $25 \mathrm{mg}(10 \mathrm{ml})^{-1}$ before and after treatment in $24 \mathrm{~h}$ tests, and 11 and $25 \mathrm{mg}(10 \mathrm{ml})^{-1}$ before and after treatment in $5 \mathrm{~h}$ tests.

Growth inhibition $(\%)$ by antibiotics at different concentrations

\section{Treatment}

Cycloheximide, $24 \mathrm{~h}$

Cycloheximide, $5 \mathrm{~h}$

Tetracycline, $24 \mathrm{~h}$

Tetracycline, $5 \mathrm{~h}$

Chloramphenicol, $24 \mathrm{~h}$

Chloramphenicol, $5 \mathrm{~h}$

Erythromycin, $24 \mathrm{~h}$

Erythromycin, $5 \mathrm{~h}$

$\begin{array}{cccc}1 \mu \mathrm{g} \mathrm{ml}^{-1} & 10 \mu \mathrm{g} \mathrm{ml}^{-1} & 100 \mu \mathrm{g} \mathrm{ml}^{-1} & 500 \mu \mathrm{g} \mathrm{ml}^{-1} \\ 98 & - & - & - \\ 99 & - & - & - \\ 49 & 83 & 99 & - \\ 14^{*} & 36 & 99 & 87 \\ 0 & 1^{*} & 62 & 44 \\ - & 0 & 91 & 99 \\ 0 & 70 & 43 & 45\end{array}$

* Not statistically significant.

Table 2. Effect of antibiotics on incorporation of $\left[{ }^{3} \mathrm{H}\right]$ leucine into protein by Pythium ultimum

Triplicate $3 \mathrm{ml}$ culture samples were incubated with the antibiotics for 10 or $50 \mathrm{~min}$ then pulselabelled for $10 \mathrm{~min}$ with $\left[{ }^{3} \mathrm{H}\right]$ leucine $(75000$ c.p.m.), after which $5 \%$ trichloroacetic acid-insoluble radioactivity (protein) was measured.

\begin{tabular}{lcccc}
\multicolumn{1}{c}{ Antibiotic } & $\begin{array}{c}\text { Radioactivity } \\
\text { (c.p.m.) }\end{array}$ & $\begin{array}{c}\text { Inhibition* } \\
(\%)\end{array}$ & $\begin{array}{c}\text { Radioactivity } \\
\text { (c.p.m.) }\end{array}$ & $\begin{array}{c}\text { Inhibition* } \\
(\%)\end{array}$ \\
None & 12507 & 0 & 12946 & 0 \\
Cycloheximide $\left(1 \mu \mathrm{g} \mathrm{ml}^{-1}\right)$ & 876 & $93(90-96)$ & 195 & $98(98-99)$ \\
Tetracycline $\left(100 \mu \mathrm{g} \mathrm{ml}^{-1}\right)$ & 5681 & $55(39-76)$ & 1295 & $90(85-95)$ \\
Chloramphenicol $\left(500 \mu \mathrm{g} \mathrm{ml}^{-1}\right)$ & 7128 & $43(29-54)$ & 7029 & $46(34-54)$ \\
Erythromycin $\left(500 \mu \mathrm{g} \mathrm{ml}^{-1}\right)$ & 12194 & $3(0-7)$ & 12910 & $0(-3-3)$
\end{tabular}

* Values in parentheses are ranges of means in three or more experiments.

In similar 5 h experiments, neither streptomycin nor penicillin $\mathrm{G}$ had any effect on growth at concentrations of up to $1 \mathrm{mg} \mathrm{ml}^{-1}$.

\section{Antibiotic effects on precursor incorporation}

In 10 to $15 \mathrm{~min}$ pulse periods, $P$. ultimum incorporated $\left[{ }^{3} \mathrm{H}\right]$ leucine selectively into protein, which could be measured conveniently as the total TCA-insoluble radioactivity (Rawn \& Van Etten, 1978). TET and CAM reduced that incorporation by 40 to $50 \%$ within $20 \mathrm{~min}$; $\mathrm{CHI}$ inhibition was essentially complete in this period (Table 2). By $60 \mathrm{~min}$, the TET inhibition reached $90 \%$; in contrast, that of CAM did not change. In separate experiments, the CAM inhibition remained at about $40 \%$ for $5 \mathrm{~h}$. In the same experiments, the lack of ERY inhibition, as shown in Table 2, was maintained for $5 \mathrm{~h}$. Identical results were obtained with each of the antibiotics when $\left[{ }^{3} \mathrm{H}\right]$ phenylalanine was substituted for $\left[{ }^{3} \mathrm{H}\right]$ leucine as a precursor.

At concentrations of TET and CAM which rapidly reduced leucine incorporation by $P$. ultimum, neither antibiotic significantly reduced leucine incorporation by the yeast Saccharomyces cerevisiae, with treatments of up to $3 \mathrm{~h}$ (Table 3). However, CHI was completely inhibitory. Since this yeast exemplifies eukaryotic insensitivity to such antibacterial agents, these results illustrate the unusual sensitivity of $P$. ultimum. 
Table 3. Effect of antibiotics on incorporation of $\left[{ }^{3} \mathrm{H}\right]$ leucine into protein by Saccharomyces cerevisiae

Triplicate $3 \mathrm{ml}$ culture samples were incubated with the antibiotics for $3 \mathrm{~h}$, then pulse-labelled for $10 \mathrm{~min}$ with $\left[{ }^{3} \mathrm{H}\right]$ leucine $(75000$ c.p.m.), after which $5 \%$ trichloroacetic acid-insoluble radioactivity (protein) was measured.

$\begin{array}{lcc}\quad \text { Antibiotic } & \begin{array}{c}\text { Radioactivity } \\ \text { (c.p.m.) }\end{array} & \begin{array}{c}\text { Inhibition* } \\ (\%)\end{array} \\ \text { None } & 21064 & 0 \\ \text { Cycloheximide }\left(1 \mu \mathrm{g} \mathrm{ml}^{-1}\right) & 218 & 99(98-99) \\ \text { Tetracycline }\left(100 \mu \mathrm{g} \mathrm{ml}^{-1}\right) & 20223 & 4(0-8) \\ \text { Chloramphenicol }\left(500 \mu \mathrm{g} \mathrm{ml}^{-1}\right) & 19161 & 9(8-9) \\ * \text { Values in parentheses are ranges of means in three experiments. }\end{array}$

Table 4. Effect of antibiotics on transport of $\left[{ }^{3} \mathrm{H}\right]$ leucine into Pythium ultimum

Triplicate $5 \mathrm{ml}$ culture samples were incubated for 15 or $45 \mathrm{~min}$ with $1 \mu \mathrm{g}$ cycloheximide $\mathrm{ml}^{-1}$ plus the antibiotics indicated, then pulse-labelled for $15 \mathrm{~min}$ with $\left[{ }^{3} \mathrm{H}\right]$ leucine $(150000 \mathrm{c.p} . \mathrm{m}$.). Cells were then filtered and washed, and radioactivity soluble in $80 \%$ ethanol $\left(90^{\circ} \mathrm{C}\right)$ was measured.

\begin{tabular}{|c|c|c|c|c|}
\hline \multirow[b]{2}{*}{ Antibiotic } & \multicolumn{2}{|c|}{30 min treatment } & \multicolumn{2}{|c|}{60 min treatment } \\
\hline & $\begin{array}{l}\text { Radioactivity } \\
\text { (c.p.m.) }\end{array}$ & $\begin{array}{c}\text { Inhibition* } \\
(\%)\end{array}$ & $\begin{array}{l}\text { Radioactivity } \\
\text { (c.p.m.) }\end{array}$ & $\begin{array}{c}\text { Inhibition* } \\
(\%)\end{array}$ \\
\hline None (cycloheximide only) & 25267 & 0 & 31717 & 0 \\
\hline Tetracycline $\left(100 \mu \mathrm{g} \mathrm{ml}^{-1}\right)$ & 10823 & $57(47-73)$ & 9642 & $70(58-83)$ \\
\hline Chloramphenicol $\left(500 \mu \mathrm{g} \mathrm{ml}^{-1}\right)$ & 15729 & $38(29-45)$ & 20933 & $34(23-48)$ \\
\hline Erythromycin $\left(500 \mu \mathrm{g} \mathrm{ml}^{-1}\right)$ & 24781 & $2(-9-9)$ & 32129 & $0(-5-3)$ \\
\hline
\end{tabular}

* Values in parentheses are ranges of means in three or more experiments.

In a series of experiments identical to those reported in Table 2, the effects of antibiotics on $\left[{ }^{14} \mathrm{C}\right]$ acetate incorporation by $P$. ultimum were assayed. Control culture samples supplied with 550000 c.p.m. incorporated about 150000 c.p.m. into TCA-insoluble material in a $10 \mathrm{~min}$ pulse period. In contrast to results with leucine, none of the four antibiotics tested significantly reduced acetate incorporation within $20 \mathrm{~min}$. Although acetate products were not identified, our observations indicated that leucine and acetate incorporation activities were independent of one another during the first $20 \mathrm{~min}$ of treatment. We took advantage of this independence to test the possibility that the rapid inhibitions of leucine incorporation by TET and CAM resulted from reduced energy availability; inhibition of respiration has been reported for a few CAM-treated eukaryotes (Pestka, 1975). Within the first 20 min of treatment, leucine and acetate incorporation activities were inhibited equally (50 to $95 \%$ ) by substances known to impair energy availability: $10^{-5} \mathrm{M}$-2,4-dinitrophenol, $10^{-4} \mathrm{M}-\mathrm{NaN}_{3}$, $10^{-4} \mathrm{M}-\mathrm{KCN}$ and $10^{-2} \mathrm{M}$-malonic acid. These results do not rule out the possibility of antibiotic effects on respiration, but they do suggest that the early TET and CAM inhibitions of amino acid incorporation into protein were not due to antibiotic impairments of energy generation.

\section{Antibiotic effects on leucine transport}

To determine whether TET and CAM might reduce leucine incorporation into protein by inhibiting leucine transport into the cell, transport was assayed with cells treated with $\mathrm{CHI}$ to abolish protein synthesis. The virtually complete $\mathrm{CHI}$ inhibition of leucine incorporation shown in Table 2 occurred within 5 min (Rawn \& Van Etten, unpublished). Both TET and CAM inhibited leucine transport within $30 \mathrm{~min}$ (Table 4). As in the incorporation experiments, ERY had no effect on leucine uptake. The same results were obtained with $\left[{ }^{3} \mathrm{H}\right]$ phenylalanine as a precursor. The amino acid measured in these experiments was free in the cell, since $95 \%$ of the radioactivity taken up by the cells was soluble in either hot $80 \%$ ethanol or $5 \%$ TCA. 
Table 5. Effect of antibiotics on protein synthesis by Pythium ultimum

Triplicate $5 \mathrm{ml}$ culture samples were incubated for $45 \mathrm{~min}$ with the antibiotics, then pulse-labelled for $15 \mathrm{~min}$ with [ $\left.{ }^{3} \mathrm{H}\right]$ leucine $(420000$ c.p.m.). Cells were then filtered and washed, and $80 \%$ ethanolsoluble $\left(90^{\circ} \mathrm{C}\right.$ ) radioactivity (pool) and $5 \%$ trichloroacetic acid-insoluble radioactivity (protein) were measured.

$\begin{array}{lrr}\quad \text { Antibiotic } & \text { Pool } & \text { Protein } \\ \text { None } & 24700 & 158366 \\ \text { Tetracycline }\left(100 \mu \mathrm{g} \mathrm{ml}^{-1}\right) & 24701 & 16065 \\ \text { Chloramphenicol }\left(500 \mu \mathrm{g} \mathrm{ml}^{-1}\right) & 18772 & 87163 \\ \text { Erythromycin }\left(500 \mu \mathrm{g} \mathrm{ml}^{-1}\right) & 25238 & 156405 \\ \text { Cycloheximide }\left(1 \mu \mathrm{g} \mathrm{ml}^{-1}\right) & 60706 & 2521 \\ \quad * \text { Values in parentheses are ranges of means in four experiments. }\end{array}$

Leucine incorporation into protein*

$(\%)$

$86(84-87)$

$39(39-42)$

$82(74-86)$

$86(85-87)$

$4(3-5)$

\section{Antibiotic effects on protein synthesis}

A comparison was made of the distribution of $\left[{ }^{3} \mathrm{H}\right]$ leucine between the cell pool and protein in cells pulse-labelled for $15 \mathrm{~min}$ after incubation for $45 \mathrm{~min}$ with various antibiotics (Table 5). In untreated cells about $85 \%$ of the leucine taken up was incorporated into protein and $15 \%$ was in the cellular pool. This proportion was quite consistent among experiments as long as the ambient $\left[{ }^{3} \mathrm{H}\right]$ leucine concentration did not become limiting. Exhaustion of ambient precursor led to a decrease in pool radioactivity and a corresponding relative increase in protein radioactivity. The same 85:15 distribution was found in cells treated with ERY, which has been shown to have no effect on transport or net incorporation. With CHI treatment, virtually all of the $\left[{ }^{3} \mathrm{H}\right]$ leucine taken up by the cells was in the pool, and the pool was consistently larger. This result suggested that protein synthesis normally limited the pool size and that the leucine permease did not turn over significantly during the 60 min test period (in the 20 to 60 min uptake experiments as well). With CAM treatment, the ratio of protein to pool radioactivity did not differ significantly from that in untreated or ERY-treated cells, even though CAM reduced the amount of leucine in the cell by about $40 \%$. Thus, CAM did not inhibit protein synthesis per se; its effect on net amino acid incorporation could be accounted for quantitatively by its inhibition of transport. With TET treatment, however, the percentage of $\left[{ }^{3} \mathrm{H}\right]$ leucine in protein was greatly reduced, an indication that TET inhibited protein synthesis as well as amino acid transport.

It should be noted that this TET effect on protein synthesis did not account for the effect on transport, e.g. via reduced permease synthesis, since protein synthesis in the transport experiments had been blocked by CHI. Conversely, the similar pool radioactivities in untreated and TET-treated cells (Table 5) indicated that limiting leucine availability did not account for the decrease in the percentage of protein radioactivity caused by TET. Thus, the two effects of TET appear to be independent of one another.

The radioactivity data of Table 5 are the average of four experiments in which, individually, the TET effect on pool radioactivity varied from a $67 \%$ reduction to a $50 \%$ increase. This probably indicated that the TET effects varied in relative dominance between experiments. The effect on transport would tend to decrease pool radioactivity, whereas the effect on protein synthesis would tend to increase pool radioactivity, just as CHI did. The data of Table 5 suggest that the inhibition of protein synthesis by TET may be as high as $90 \%$.

Streptomycin and penicillin $\mathrm{G}$ served as additional controls in that, at concentrations up to $1 \mathrm{mg} \mathrm{ml}^{-1}$, neither inhibited leucine or acetate incorporation, leucine transport or protein synthesis in the experiments described. The results were essentially the same as those with ERY, except in growth inhibition experiments where ERY was inhibitory. 


\section{DISCUSSION}

The direct impairment of amino acid transport by TET and CAM places at least one site of antibiotic action at the cell surface. However, the site of the direct inhibitory effect of TET on protein synthesis could be either the cytoplasmic or mitochondrial ribosome. The eukaryotic mitochondrial protein synthesis system (MPS) is typically sensitive to low concentrations of such drugs in vitro, but it produces only a few per cent of the total cellular protein mass; the great bulk, including most of the mitochondrial proteins, is produced by the cytoplasmic protein synthetic system (Schatz \& Mason, 1974). The CHI data reported here indicate that this relation holds in our $P$. ultimum isolate. The only reported shortterm effect of impaired MPS activity on cytoplasmic protein synthesis is not an inhibition but an accumulation in the cytoplasm of cytoplasmically produced peptides destined for transport into mitochondria (Schatz \& Mason, 1974). Therefore, an inhibition of the MPS by TET does not satisfactorily explain the large inhibition of protein synthesis in $P$. ultimum during the first hour of treatment. The alternative explanation that TET has a direct effect on the cytoplasmic protein synthetic system is the most logical. This is consistent with reports of in vitro inhibition of the cytoplasmic system by TET (Pestka, 1971); however, eukaryotes are typically insensitive to TET in vivo.

The results with ERY, which differed strikingly from those with TET and CAM, are consistent with the interpretation that its primary effect is an inhibition of the MPS. First, a dose increase above that sufficient to block MPS activity would not further decrease growth within one doubling period, in keeping with the ERY data of Table 1. Second, the lack of ERY inhibition of protein synthesis is consistent with the expectation that the MPS contributes only a very small amount to total cell protein synthesis. A few per cent would be masked even by a small experimental error in measuring net protein synthesis. Further, as noted above, reduced MPS activity does not dictate a large or rapid reduction in cytoplasmic protein synthesis. Third, growth inhibition could reflect impaired construction of new mitochondria, but this need not preclude support of cytoplasmic protein synthesis by functional mitochondria already present. The lack of mitochondrial construction beyond one doubling period should reduce growth further; indeed, treatment with ERY for $24 \mathrm{~h}$ inhibited growth completely.

As noted in the Introduction, inhibition of the MPS does not satisfactorily explain the antibiotic sensitivity of pythiaceous fungi. It is probable that eukaryotic cells typically exclude the drugs (Lamb et al., 1968), as do many insensitive bacteria (Dowding \& Davies, 1975). In contrast, streptomycin sensitivity of some members of the Pythiaceae was attributed to increased absorption of this drug (Voros, 1965). The TET inhibition of protein synthesis reported here indicated that TET rapidly entered the cell. Unusual permeability properties were indicated also by the TET and CAM transport effects reported here and by the atypical insensitivity of the Pythiaceae to membrane-active polyene antibiotics (Hendrix, 1974). Therefore, it is probable that where an inhibition of the MPS is the major druginduced dysfunction, it is access of the drug to the MPS that accounts for the unusual sensitivity.

The combined effects of TET on transport and protein synthesis clearly seem sufficient to produce the complete inhibition of growth observed. However, with CAM, which directly impairs some transport activity, a possible effect on the MPS, given time, cannot be ruled out as the growth inhibitory effect of primary importance. The results of this investigation indicate that antibacterial antibiotic sensitivity of the Pythiaceae has multiple bases and that each basis may ultimately be a function of the unusual permeability properties of these fungi.

We thank Mr Randy Fawl for technical assistance. This work, conducted under Nebraska Agricultural Experiment Station Project no. 21-17, was supported in part by Public Health 
Service Grant AI-08057 from the National Institute of Allergy and Infectious Diseases. It is published with the approval of the Director as paper no. 5479, Journal Series, Nebraska Agricultural Experiment Station.

\section{REFERENCES}

Carnes, D. W. \& Leary, J. V. (1977). The sensitivity of Phytophthora palmivora to chloramphenicol. Proceedings of the American Phytopathological Society 4, 94-95.

De Vries, H., Agsteribbe, E. \& Kroon, A. M. (1971). The 'fragment reaction': a tool for the discrimination between cytoplasmic and mitochondrial ribosomes. Biochimica et biophysica acta $246,111-122$.

Dowding, J. \& Davies, J. (1975). Mechanisms and origins of plasmid-determined antibiotic resistance. In Microbiology-1974, pp. 174-186. Edited by D. Schlessinger. Washington, D.C.: American Society for Microbiology.

Grivell, L. A. (1967). Amino acid incorporation by mitochondria isolated, essentially free of microorganisms, from Saccharomyces carlsbergensis. Biochemical Journal 105, 44C-46c.

HENDRIX, J. W. (1974). Physiology and biochemistry of growth and reproduction in Pythium. Proceedings of the American Phytopathological Society 1, 207-210.

Lamb, A. J., Clark-Walker, G. D. \& Linnane, A. W. (1968). The biogenesis of mitochondria 4: the differentiation of mitochondrial and cytoplasmic protein synthesizing systems in vitro by antibiotics. Biochimica et biophysica acta 161, 415-427.

Marchant, R. \& Smith, D. G. (1968). The effect of chloramphenicol on growth and mitochondrial structure of Pythium ultimum. Journal of General Microbiology 50, 391-397.

PestKA, S. (1971). Inhibitors of ribosome function. Annual Review of Microbiology 25, 487-562.

PestKa, S. (1975). Chloramphenicol. In Antibiotics Vol. III. Mechanism of Action of Antimicrobial and Antitumor Agents, pp. 370-395. Edited by J. W. Corcoran \& F. E. Hahn. New York: Springer Verlag.

Rawn, C. D. \& Van EtTen, J. L. (1977). Antibiotic inhibition of protein synthesis in Pythium ultimum. Proceedings of the American Phytopathological Society 4, 128-129.

Rawn, C. D. \& Van EtTen, J. L. (1978). A shake culture method for Pythiaceae applicable to rapid, small-scale assay of vegetative physiology. Phytopathology (in the Press).

Schatz, G. \& Mason, T. L. (1974). The biosynthesis of mitochondrial proteins. Annual Review of Biochemistry 43, 51-87.

Tsao, P. H. (1970). Selective media for isolation of pathogenic fungi. Annual Review of Phytopathology 8, $157-186$

Van Etten, J. L., Vidaver, A. K., Koski, R. K. \& SEMANCIK, J. S. (1973). RNA polymerase activity associated with bacteriophage $\phi 6$. Journal of Viro$\log y 12,464-471$.

Voros, J. (1965). Streptomycin sensitivity of Oomycetes due to the increased absorption of streptomycin by their mycelia. Phytopathologische Zeitschrift 54, 249-257. 